\title{
MEZZO BESTIA E MEZZO UOMO: CÉSAR BÓRGIA, DON JUAN E OS SARAUS DE SUBÚRBIO
}

Benito Martinez Rodriguez ${ }^{*}$

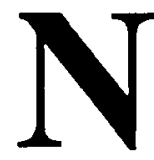

a introdução ao seu principal estudo' sobre Lima Barreto, Osman Lins se indaga da adequação de produzir uma tese de doutorado sobre as obras de um autor que tinha tão severa avaliação das instituições acadêmicas de seu tempo. De fato, é dificil pensar em algum exemplo de homem de letras brasileiro que tenha manifestado menor estima por doutores.

O crítico não sugeriu outra resposta para a interrogação senão a confiança numa hipotética boa-vontade com que Lima Barreto haveria de acolher o interessado estudo de um intelectual que se apresentava não tanto como crítico, mas como companheiro do mesmo oficio de narrar.

Tal preocupação de Osman Lins, embora formulada em tom retórico, é reveladora. Guiados e estimulados fartamente pelo próprio autor a ler seus

* Universidade Federal do Paraná (benito@cce.utpr.br)

I LINS. Osman. Lima Barreto e o espaço romanesco. São Paulo: Ȧtica. 1976. (Col. Ensaios, 20) 
trabalhos como depoimentos, verdadeiros documentos de uma época, parcela ponderável dos criticos de Lima Barreto tendeu a desconsiderar as possibilidades de interpretação de sua obra que se pusessem fora do círculo imediato do empenho na questão social, seja em sua dimensão econômica, seja na racial. ${ }^{2}$

Ao examinar-Ihe os trabalhos, não poucas vezes, a textura de seus escritos foi posta em plano secundário. Aqueles que o avaliaram positivamente se inclinaram a fazê-lo apontando nas suas criações o admirável panorama do Rio de Janeiro da Belle Époque, sua atenção aos cenários suburbanos e o interesse pelos tipos pobres e marginais da velha capital; os que o julgaram negativamente, o fizeram muito freqüentemente baseando suas afirmações no argumento de que essas mesmas características louvadas por seus admiradores enfraqueciam a densidade dos trabalhos ficcionais de Lima Barreto, transformando-os ora em reportagem, ora em confissão, e não raro, num misto das duas coisas. E, o que seria ainda mais grave, tal promiscuidade entre o universo da ficção e o mundo da experiência estaria vazada numa linguagem defeituosa, seja quanto à correção gramatical, seja quanto à eficiência narrativa.

Numa das páginas do seu Dićrio intimo ${ }^{3}$ podem ser lidas as seguintes palavras de Lima Barreto:

Aqui bem alto declaro que. se a morte me surpreender. nào permitindo que as inutilize las amargas notas pessoais daquele dial. peço a quem se servir delas que se sirva com o máximo cuidado e discriçào, porque mesmo no túmulo eu poderia ter vergonha. (XIV. 77)

Ainda que expressa de maneira ingênua, essa recomendação do autor foi, de modo involuntário que seja, amplamente satisfeita por grande parte de seus críticos. Qual seria, porém, o resultado de uma leitura que desconsiderasse os

2 i: importante registrar o surgimento, desde a década de 70 . de värios trabalhos que. seguindo por diferentes caminhos de leitura e utilizando recursos de análise os mais diversos. se desviaram desses roteiros tradicionais da critica limabarretiana. Dentre eles. se podem destacar os cstudos monográlicos de Osman L.ins. Carlos lirivani Fantinati e Antonio Arnoni Prado. leituras de Silviano Santiago. de Nicolau Sevecnko e Flora Süssekind. Nào se deve esquecer, contudo. que aspectos da entranhada tradiçào de leitura das obras do escritor carioca persistem em muitos outros trabalhos desse mesmo período. seja como residuo. seja como estrutura fundamental. Ė no caso dos trabalhos a respeito de Clara dos Anjos. sua persistència se revela especialmente vigorosa.

3 Todas as referências a trabalhos de Lima Barreto neste artigo remeterăo à ediçăo das Ohras Completas do autor. de 1956. A numeração entre parênteses, após as citaçoes. indica o volume, em numerais romanos. e a página, em algarismos aräbicos. As referências completas estào na lista bibliogrática ao final do ensaio. 
pudores do escritor e descuidasse da identificação dos referenciais biográficos desses escritos?

O presente trabalho sugere uma abordagem propositalmente desavergonhada dos textos de Lima Barreto, sobretudo da derradeira versão de Clara dos Anjos $^{4}$. Uma leitura que confie menos no depoimento do autor e acredite mais nas potencialidades de seu texto. Longe de julgar irrelevantes as propostas estético-filosóficas declaradas pelo escritor no conjunto de sua obra, a idéia é extrair da produção limabarretiana sentidos que possivelmente ele não considerara quando da redação dos trabalhos. Ou, se tanto, apenas os intuira de modo vago e impreciso.

Talvez seja possivel ler esse romance como uma tentativa, sob diversos aspectos malograda, de Lima Barreto alcançar um público leitor que sempre fora um alvo de seus interesses.

Mais do que isso, porém, e aí o fracasso junto ao público importa menos, trata-se de empreender a leitura de Clara dos Anjos à luz das mudanças expressivas no ambiente cultural do Rio de Janeiro de então. Tais modificações se articulam, é claro, com todo o quadro de profundas transformações ocorridas na velha capital (e de resto, no país), conjunto de fenômenos que, durante os

4 Sob o título Clara dos Anjos, Lima Barreto produziu três trabalhos diterentes ao longo de dezoito anos de carreira:

1- O primeiro texto, datado de 1904 e publicado pela primeira vez na edição das Obras Completas do autor em 1956. é o projeto de um longo romance jamais concluido. tendo restado dele os quatro capitulos iniciais apenas esboçados. $\mathrm{cm}$ grau decrescente de acabamento. sendo o primeiro bastante elaborado e os demais progressivamente mais esquemáticos, revelando-se, pelas próprias anotaçðes marginais do autor nos manuscritos. rascunhos a serem enxertados e ampliados:

II- O segundo texto é um conto cuja primeira publicação data de 1919. na ediça de dezembro da revista América Latina. e que, no ano seguinte, integrou a coletânea Histórias e sonhos, do autor: III- A última versão é o pequeno romance datado pelo autor de fins de 1921. principios de 1922. tendo sido publicado apenas após sua morte. primeiramente em forma seriada. na revista Souza Cruz. de janciro de 1923 a maio de 1924 e. mais tarde. no ano de 1948. em volume.

A parte principal desses textos se encontra publicada nas Obras Completas do autor. Os manuscritos remascentes desses trabalhos. arrolados na Coleçăo Lima Barreto da Biblioteca Nacional do Rio de Janeiro, correspondem a toda a primeira versão. incluindo alguns fragmentos atć hoje inéditos. $\mathrm{e}$ um autógrafo do conto. A totalidade dos très conjuntos textuais. isto ć. as ediçeses mencionadas $\mathrm{e}$ os autógrafos correspondentes, podem ser tomados como instantes de um projeto literário que sofreu. ao longo de dezoito anos. consideráveis modificaçðes. Para adequar a discussão aos limites de um artigo acadêmico, os comentários no presente ensaio estarào concentrados na versào final da obra. Uma discussão mais ampla. que procurou articular na mesma perspectiva as várias redaçues de Clara pode ser encontrada em meu trabalho Duelo ou dueto: a indecisa posição da literatura frente ao mundo moderno em Clara dos Anjos de Lima Barreto. dissertaçăo de mestrado apresentada à FFLCII-USP em 1993. Outro exercicio de leitura do conjunto destes textos de l.ima Barreto. cm clave teórica e crítica inteiramente distinta pode ser encontrada em TEIXEIRA. Vera Regina de. "Clara dos dinjos de Lima Barreto: biópsia de uma sociedade". In: Luso-Brazilian Review: Madison. Wisconsin. v. 17. n. 1. p.41-50. 1980. 
turbulentos anos da República Velha, afetaram desde a arquitetura e os serviços da cidade até à própria estrutura de suas relações sociais. Este é o propósito do presente ensaio.

A idéia aqui não é fazer dos textos documentos para o estudo daquele periodo, no sentido em que os historiadores utilizariam o termo. Na verdade, nas várias redações desse trabalho do ficcionista carioca, na sua trajetória, em suas imagens, nas mudanças e permanências do texto, pode-se perceber indices do modo de relação do autor com a emergência de toda uma série de novas formas de expressão artística, fundadas em recursos da revolução técnica que marca a passagem para o nosso século. Dentre elas, avulta em importância a música popular urbana, então em processo de ampliação de público e profissionalização de seus artistas. Tal fenômeno guarda estreita relação com a popularização das revistas teatrais cantadas, com a introdução e expansão das várias formas de registro e reprodução eletromecânica do som, e a implantação do cinema. Esses novos meios de expressão se voltam para um público que, mesmo de modo incipiente, ensaiava o processo de massificação no Brasil ${ }^{5}$.

Acompanhando o fluir do trabalho de Lima Barreto em Clara dos Anjos, pode-se compreender o impacto da reordenação do quadro cultural no período sobre a produção do autor. As repetidas reelaborações do projeto original do autor, até alcançar a forma final já no final de sua vida, apontam para uma tentativa de responder a essas novas demandas e condições, extremamente desafiadoras e complexas.

\section{Uma tradição nada afortunada}

Não foram muitos os que se dedicaram a escrever especificamente sobre Clara dos Anjos. Tal escassez de interesse por si só parece refletir o juízo pouco lisonjeiro que grande parte da crítica tem desses textos. Estudo básico nessa escassa coleção é o trabalho de Sérgio Buarque de Holanda que serviu de prefácio à segunda edição em volume do romance, integrando as Obras Com-

5 Aqui se tem em mente as análises presentes em dois trabalhos: Literatura como missão. de Nicolau Sevcenko, c Cinematógrafo de Letras, de Flora Süssekind. No primeiro, o historiador insere Lima Barreto dentro do quadro de transformaçðes do Rio de Janeiro das primeiras décadas do século XX, estudando como as condições históricas do periodo exerceram notável influência na formação intelectual do ficcionista e interferiram decisivamente na sua produçăo literária. Já no segundo trabalho, a ensaista analisa com rara agudeza os múltiplos modos de interferência e as complexas interpenetraçðes entre o processo de modernização do Brasil, do Rio de Janeiro em especial, e a produção literária. 
pletas do autor. Nele $o$ analista toca em vários dos pontos fundamentais da relação entre a crítica e a produção de Lima Barreto em geral, e de Clara em particular. Em seu fecho, o analista sintetiza admiravelmente sua leitura do autor carioca:

Essa filosofia [compensar pela Arte as injustiças da sociedade] projeta-se de algum modo sobre todos os aspectos da obra de Lima Barreto, e porque ele a viveu intensamente. nem sempre pôde distanciar-se o bastante para dar lugar a uma verdadeira perspectiva artistica. Dessa ausência de perspectiva decorrem certamente algumas qualidades e muitos defeitos dessa obra. Pode-se dizer que em Clara dos Anjos temos um compêndio desses defeitos. Mas é também. de todos os seus romances. aquele onde ele menos se oculta, aquele. talvez. onde deixa melhor entrever os caminhos de seu espírito e sua arte. Para os que verdadeiramente estimam a obra do romancista carioca. os próprios defeitos tornam-se. neste caso. uma virtude incomparável. (v. [19])

Ai se tem um verdadeiro paradigma da posição da crítica do periodo imediatamente seguinte àquele em que viveu o autor. Como pensador modernista, incomoda a Sérgio Buarque de Holanda a convencionalidade da técnica do escritor: "[...] essa arte [de Lima Barreto] não denuncia a menor preocupação com as técnicas que servissem para enriquecê-la ou renová-la" (v. [16]). Por outro lado, demonstra uma simpatia que, reprimida pelas conviç̧̃es teóricas durante boa parte da análise, ganha espaço na conclusão do ensaio, ao reconhecer que os mesmos traços que the são apontados como "defeitos", podem ser lidos, de um outro ponto de vista, como algumas das maiores virtudes do escritor ${ }^{6}$.

- Sobre as atitudes da critica da geraçao de 1922 conı relação a Lima Barreto. vcja-se as palavras de Sérgio Milliet no seu Diário Critico a 17 de setembro de 1952: "Lima Barreto foi o grande romancista da geraçao pós-machadiana e o pioneiro do romance moderno brasileiro. Admiraram-no os revolucionários de 22 pelo seu estilo direto e limpo [...] como o admiravam pela verdade algo caricatural de seus heróis e pela mordacidade de sua critica social. Por outro lado viam nele a primeira revolta declarada contra o preconceito de cor. até entào considerado. por necessidade de recontorto moral dos brancos, como não existente entre nós. "Depois desse entusiasmado clogio. Sérgio Millet admite o descompasso entre a sua geração e o ficcionista carioca durante o breve período de contemporaneidade que tiveram: "Falei da posição de Lima Barreto ante a geraçào de 22. Na verdade referia-me principalmente ao pensamento intimo do grupo modernista. De público discutiamos com o romancista e nào dávamos o braço a torcer. [...] Compreende-se. $A$ época era de polèmica e de atirmação." Diärio critico de... São Paulo: Martins. v.8. 1955. respectivamente, p. 245 e 248. 
Fica nítida neste estudo, uma certa tendência dos analistas de Lima Barreto criticarem o autor não tanto pelos textos que escreveu, mas pelos que "poderia", ou até "deveria", ter escrito, com o "talento que Deus lhe deu", para usar a expressão do mesmo Sérgio Buarque de Holanda, caso tivesse controlado suas expansões confessionais e descuidos de estilo.

Em Clara, o fato de a trama girar em torno da sedução de uma jovem negra da baixa classe média suburbana por um rapaz branco de posição social superior à sua, só acentua a propensão a encarar o texto de Lima Barreto como exercício confessional. Contudo, ler tais narrativas, particularmente a derradeira versão, desse modo, acabaria por empobrecer sobremaneira a compreensão da natureza ficcional dos trabalhos, bem como a percepção de seu lugar no conjunto da produção limabarretiana.

\title{
Os olhos e os ouvidos
}

Na última das versões de Clara dos Anjos, a festa de aniversário da protagonista, além de ser o cenário que propicia o desencadeamento do processo de sedução, acaba por transformar-se em uma arena onde, no decorrer do flerte, desenvolve-se um verdadeiro embate entre vários artistas suburbanos. Mais do que disputarem a atenção do público, Clara em especial, os oponentes se enfrentam como encarnações de pontos de vista artísticos diversos.

O primeiro a se apresentar nesta disputa é Cassi Jones de Azevedo, intérprete suburbano, futuro sedutor da protagonista. $O$ ficcionista registra para o leitor duas estrofes da modinha que ele canta:

\author{
Mostraram-me um dia \\ Na roça dançando \\ Mestiça formosa \\ De olhar azougado...
}

7 Fábio Lucas censura no escritor carioca a incapacidade de libertar-se de seu "drama pessoal", vendo ai a explicação para uma alegada falta de profundidade no tratamento dado pelo ficcionista à questão racial: É certo que Lima Barreto teve vagas noções da revolução russa, chegou a vislumbrar a influência do latifúndio na desigualdade social (...), mas circustâncias de sua vida. o seu ressentimento, a sua "boa fé desarmada" reduziram a visão da totalidade e ele não fez a análise que podia, o romance social que a sua época já comportava. Pesavam-lhe demais a humilhação, o sentimento de inferioridade." O caráter social da ficçào do Brasil. São Paulo: Ática, 1985, p. 25. Caberia perguntar ao crítico quem, naqueles anos, teria realizado esse "romance social que a época de Lima Barreto comportava". 
Sorria a mulata

Por quem o feitor

Diziam que andava

Perdido de amor. $(v, 80-1)^{8}$

Versos redondilhos menores, de ritmo popular e gosto romântico, tematizam um amor que suplanta barreiras sociais e raciais. A mulata de olhar esperto, "azougado", pela dança e pelo sorriso seduz e subjuga o seu feitor. De depositário do poder na relação com a escrava, o feitor se torna escravo dela graças aos seus encantos e esperteza.

A literatura romântica, da qual estão impregnados os versos da modinha, é apresentada como ilusão e falseamento da realidade das relaçð̃es sociais, onde tal inversão não poderia se dar, mais ainda porque a esperteza da mulata não tem como exemplo a personagem Clara. O "olhar azougado" não é o dela. mas o de Cassi, que neste momento exercita seu poder de sedução pela canção e pelo jogo com os olhos.

Comentando a interpretação de Cassi Jones, o tom do narrador é francamente negativo. Não possui "modulação alguma" e a execução do violão é de "uma indigência musical" desanimadora. Isso, contudo, não impede sua magnifica aceitação pelo público. A apresentação de Cassi é bem-sucedida. $\mathrm{O}$ narrador destaca como chave do sucesso o seu já mencionado " $t i c$ invencivel": "Cantando, revirava os olhos e como que os deixava morrer." $(v, 81)$

8 Os versos da modinha pertencem a Gonçalves Crespo. O poema original nào se intitula "Na roça", como nos informa a personagem, mas sim "Cançào" e é datado de 1870 . Integrou o volume Miniaturas. publicado originalmente no ano seguinte. A confusão de titulos pode se dever ao fato de existir um famoso poema do escritor luso-brasileiro que tem por nome essa cxpressào. "na roça", que aparece no verso de abertura de "Cançåo". $O$ álbum fonográfico Canıares Brasileiros, no seu volume dedicado à modinha e ao lundu, registra a adaptaçào completa do poema de Gonçalves Crespo para a forma de modinha por um compositor anònimo sob o titulo "Mucama". Contudo, o editor anota que no seu tempo, a "Cançào" era também anunciada como "Mestiça" ou mesmo "Mulata". É. sem dúvida. trabalho que teve grande popularidade no seu tempo. Mostra disso está no fato de que Oneyda Alvarenga o apresenta como exemplo caracteristico da produça do desse gènero musical na segunda metade do século XIX. Mísica Popular Brasileira. p. 330-335. De resto. como observou Péricles Eugè nio da Silva Ramos, o trabalho literário de Gonçalvez Crespo exerceu. no seu tempo, significativa influência sobre os poetas brasileiros (cf. A Literatura no Brasil. v. IV. p. 99-115). Nas Miniaturas, o poema é organizado em estrofes de oito versos. sendo os quatro primeiros hendecassilabos e os restantes pentassilábicos. A distribuiçåo dos acentos nos versos da primeira metada das estrofes segue o padråo tipicamente romàntico de $2^{*}$. $5^{\text {" }}$ e $11^{\text {: }}$ silabas, 0 que permite o seu desmembramento em redondilhos menores. No texto de Lima Barrreto. foram selecionados os dois versos que abrem o poema $\mathrm{e}$, divididos ao meio. formam uma quadra pentassilábica. seguidos do quarto e quinto versos da segunda estrofe c finalizando com o último verso da primeira. 
A segunda manifestação da festa cabe ao "doutor" Praxedes Maria dos Santos. A personagem declama um soneto do qual se registram, no texto, o primeiro quarteto e os quatro versos finais:

Cismava à beira-mar, a linda Marieta, Seguindo tristemente o sulco do vapor, $O$ qual, fugindo além, sumiu-se no horizonte, Levando a longe terra o seu primeiro amor.

Depois, quando o luar banhando a natureza Em pálidos clarões de luz misteriosa, Eu vi no arrebentar do mar embravecido A lágrima a boiar na pétala de rosa. (v. 82)

São alexandrinos com cesura na sexta sílaba, metro parnasiano por excelência, atribuídos a um certo major Urbano Duarte. Carregado de clichês que eram norma na nossa poesia dos princípios do século $\mathrm{XX}$, como a atenção à metrificação dodecassilábica, a presença da aliteração em $L$ e $R$ nos versos finais, o sentimentalismo artificial e a curiosa "antítese" da expressão pálidos clarões, estes versos são declamados, segundo o narrador, de modo tão grotesco quanto o era a aparência da personagem ${ }^{9}$. Um inútil comentário final, explicando

9 A personagem Praxedes Maria dos Santos intrigou a Gregory Rabassa. Em seu trabalho O Negro na ficção brasileira. Rio: Tempo Brasileiro, 1965, ele escreve: "Outra figura secundária é um negro que recebeu educą̧ão e quer ser tratado de doutor. Lima Barreto é bastante irônico nessa descrição. Está, outra vez, consciente dos aspectos fisicos do negro e descreve os desse homem em detalhe. Essa preocupação com a posição do negro que está se elevando na sociedade ocorre muito frequentemente na obra de Lima Barreto, ainda que nunca num grau de obsessão, e sua atitude muitas vezes parece irracional, e fica dificil descobrir-se exatamente o sentimento que o levou a discutir esse assunto dessa maneira." (p. 376) Talvez surpreenda ao estudioso estrangeiro a ausência, no caso daquela personagem, de uma adesão simpática do narrador, tomado como porta-voz direto do próprio Lima Barreto. Afinal, autor e personagem compartilhavam condição social e racial muito próximas. Tal atitude impediu o crítico de ver algo que Hélcio Pereira da Silva, no seu livro extremamente desigual Lima Barreto, escritor maldito. Rio. [s.e.], 1976, pôde identificar com facilidade: "Este doutor Praxedes, se repararmos bem, lembra Rui Barbosa em negativo." (p. 212) De fato, na caracterização física do personagem, se podem ver traços essenciais de uma caricatura do jurista baiano. A isso se acrescentam os fatos de a personagem se ter $\mathrm{em}$ conta de grande entendido em assuntos de Direito e, o que parece mais significativo, gostar "de versos: mas não de modinha" (p. 77). Lembre-se que Rui Barbosa, durante as campanhas presidenciais de $1909 \mathrm{e} \mathrm{1919 \text {,andouàs }}$ turras com ninguém menos que Catulo da Paixão Cearense. Em 1909. partidário de Hermes da Fonseca, Catulo Cearense publicou versos em jornais do Rio de Janeiro atacando o candidato baiano. Eleito Hermes da Fonseca, seria convidado pela primeira-dama, D. Nair de Teffé, a apresentar-se num recital de modinha no palácio presidencial. Mais tarde, quando Rui Barbosa faz seu célebre 
o sentido mais do que evidente do titulo do poema, arremata a figura ridicula que se oferece da personagem.

O tom crítico do narrador é reforçado pelas atitudes das demais personagens que, a custo, contêm o riso, ou se afastam para gargalhar longe das vistas de Praxedes. Ao final do poema, a platéia, mal refeita do impacto cômico da apresentação, aplaude condescendentemente o exausto declamador.

A ausência de novidade na poesia declamada, bem como a atitude dos convidados se deixam entrever na leitura do sobrenome da personagem, "Praxedes". Praxe rotineira e mesmice capaz, se tanto, de gerar resultados cômicos.

Trata-se de uma espécie de imagem caricatural do discurso poético do século XIX, tanto nos versos, quanto no modo de declamá-los, que fracassa na tentativa de conquistar a assistência. Tal caracterização do gosto da platéia é expressiva. Pode-se ler ai uma percepção de Lima Barreto com respeito à poesia dos começos de nosso século, dando-a como desgastada formalmente e apenas aparentemente prestigiada pelo público, ao menos nos subúrbios. A uma literatura que reproduzia incansavelmente os já esgotados figurinos formais da época anterior, o público respondia encenando aprovação por mera convenção social.

O último a se apresentar na disputa é Antonio da Silva Marramaque, padrinho de Clara. Ele recita uma composição anônima, informa o narrador. publicada em um jornal antigo:

Se às vezes contigo esbarro

e grito. esperneio e berro.

que me traz de há muito zarro

a paixão que aqui encerro.

pronunciamento no Teatro Lírico. aludindo ao "Jeca Tatu". o autor de "Luar do Sertilo" uma vez mais o ataca. desta vez através do livro Serrão em Flor. Carlos de Maul. parcial issimo biögrafo do artista. insiste em que os dois se reconciliaram e para tanto, se baseia nảo só em depoimentos de contemporàneos. mas na reproduçăo fac-similar de um autógrafo de Rui Barbosa. registrado ao pé de um juizo de Júlio Dantas sobre Catulo Cearense. em um caderno onde este colecionava relèréncias elogiosas de figuras do meio intelectual a seu próprio respeito. Em várias das coletanneas de versos de Catulo Cearense. se encontram. nào transcriçöes. mas reproduçies fotográficas do lacónico elogio. A insistência em documentar. literalmente. essas palavras de Rui Barbosa. ao contrairio do que tentam fazer crer esses esforços. parece demonstrar as reservas com que o intelectual baiano via seu velho adversário político. İ: significativo que. na nota mencionada. Rui Barbosia relira-se a Catulo Cearense como poeta, nào como compositor. A figura de Catulo da Paixao Cearense e seu papel no cenário artistico do periodo foram examinadas em outro artigo de minha autoria: "Catulo da Paixalo Cearense: a derradeira vitima de Odete Roitman". Letras. Curitiba. n.44. p. 37-47, 1995. 
Tu foges. E a ti me agarro, cismando: (e nisto não erro)

Se eu tenho uma alma de barro, tu mostras que a tens de ferro.

E se nada mais espirro

é porque, então, se não corro, a coisa já cheira a esturro.

Que queres? Eu próprio embirro com este amor por que morro, mas é que sou muito burro. $(v, 83)$

Construído em versos redondilhos maiores, esse soneto foge aos padrões clássicos quanto à metrificação. A opção por um metro popular mostra-se coerente com o caráter satírico de que o texto se reveste, para o que as rimas em -arro, -erro, -irro, -orro e -urro, de efeito sonoro grosseiro, contribuem amplamente ${ }^{10}$. $\mathrm{O}$ "eu-lírico" não atina com outra explicação para o seu amor, senão sua grande burrice. Ao todo poderoso amor romântico, capaz de superar os maiores desníveis de condição social, da modinha de Cassi Jones, ou ao sentimentalismo artificial e esteticamente anacrônico do recitativo de Praxedes, opõe-se uma visão satírica. Pelo riso, se pretende, de uma só vez, explicitar a inconsistência do terreno em que se fundam ambas as propostas precedentes.

É útil comentar a caracterização que se faz da personagem. Marramaque era o padrinho de Clara. Sustentara na mocidade simpatias pelo abolicionismo e pretensões à escritor de versos, sendo que suas predileções originais recaíam sobre Casimiro de Abreu. Tendo vindo do interior do Estado do Rio de Janeiro para a capital, Marramaque pôde, graças à proteção de um amigo de seu pai, completar uma formação escolar média. Rapidamente abandonou as pretensões artísticas, pois "o seu bom senso e a integridade de seu caráter fizeram-lhe ver logo que não dava para a cousa." $(v, 39)$ No entanto, a base de sua preparação intelectual ele obtivera no convívio com os freqüentadores das rodas da boêmia literária:

"Embora atualmente fosse um simples contínuo de ministério. em que não fazia o seviço respectivo, devido a seu estado de

10 As rimas forçadas nas cinco vogais fazem lembrar alguns dos trabalhos satiricos de Gregório de Matos. Recorde-se, a propósito, o célebre soneto em -apa, -epa, -ipa, -opa, e -upa. Poemas escolhidos, p. 42. 
invalidez, de semi-aleijado e semi-paralitico do lado esquerdo. tinha. entretanto, pertencido a uma modesta roda de boimios literatos e poctas, na qual. a par da poesia e de cousas de literatura, se discutia muita política. hábito que lhe ficou. Quando veio a revolta de 93 , a roda se dissolveu. Uns foram acompanhar o Almirante Custódio: e outros. o Marechal Floriano. Marramaque foi um destes e até obteve as honras de alferes do Exército. Por ai é que teve a primeira congestão, isto é. nos tins do governo do marechal. em 94." (v. 39)

Na política, levado em parte pela experiência nas rodas intelectuais da mocidade, em parte pela sua invalidez repentina, seu temperamento era "naturalmente azedo e oposicionista" $(\mathrm{v}, 40)$. Exemplo desse comportamento se pode ver numa discussão sobre o tema da qual Marramaque toma parte na casa de Joaquim dos Anjos. Um dos presentes é de opinião que certa autoridade, doutor Saulo de Clapin, desenvolvia um bom trabalho a frente de seu cargo, do que discorda integralmente o padrinho de Clara. Interpelado a certa altura pelo adversário, Marramaque parece não ter uma boa réplica:

- Homessa. Marramaque! Vocé não leu o projeto dele sobre a construçào de casas para famílias pobres e modestas? Você nảo leu. Joaquim?

O carteiro. que vinha ouvindo a conversa sem dar opinião. à interpelação de Lafỏes. interveio:

- Li. de fato; mas li também que ele havia aumentado os alugućis de suas casas. que são inumeras, de quarenta por cento. - E isto! - acudiu com pressa Marramaque. Clapin è muito generoso com o dinheiro dos outros. do listado. Com o dele. é de uma sovinice de judeu e de uma ganancia de agiola. Iesuita! (v. 42)

A exclamação final, Jesuita!, posta no sentido figurado e pejorativo. embute uma remota dimensão anticlerical em suas palavras, constituindo o último traço da composição da síntese de certo tipo de elemento social que teve seu momento de relevância no periodo que vai do final da campanha abolicionista até a posse do nosso primeiro presidente civil: o militante florianista. De fato, oriundo de uma parcela intermediária da população, com formação intelectual igualmente mediocre, sem posses, abolicionista e republicano, Marramaque resume em si a fisionomia de toda uma camada média de nossa 
sociedade, então dando seus primeiros passos. Que o primeiro dos ataques responsáveis por sua invalidez o tenha acometido nos fins do mandato de Floriano Peixoto é dado que não se pode desconsiderar.

Para a "instrução mediocre" $(v, 63)$ da personagem tinham contribuido seus pais. Ele, um imigrante português medianamente bem- sucedido na lavoura e no pequeno comércio influíra menos no filho que, "no gênio, não saia ao pai" (v. 63). Ascendência bem maior sobre a criança tivera sua mãe, "que, embora quase branca, tinha ainda evidentes traços de índio, seria capaz de cantar o dia inteiro modinhas lânguidas e melancólicas." $(v, 64)$

Esse sentimentalismo era a medida essencial pela qual a personagem estimava o valor da literatura. Aplicando o critério não apenas ao texto, mas antes ao autor, Marramaque afeiçoava-se sobretudo pelos artistas menos conhecidos, e dentre estes, pelos mais amarguradamente sentimentais. Citando um exemplo de suas predileções poéticas, a personagem recita, por inteiro, um soneto de um de seus obscuros companheiros dos tempos de boêmia literária:

- Que alma cra esse Aquiles Varejão! Morreu há pouco tempo. em 94 ou 95; e, se não me falha a memória. na Santa Casa. Morreu na maior miséria; entretanto, tudo o que ganhava - ele era tipógrafo - estava sempre disposto a distribuir com os amigos. Não pude ir vê-lo... Tinha tido o primeiro ataque è estava em tratamento. Lembro-me, porém, do seu último soneto que a Gazeta publicou. Que lindeza! Aquilo era poeta que não forçava. nem tinha compasso e régua. Ouça só!

E. com um a voz dificil. devido à semiparalisia da parte esquerda da boca. esbugalhando os olhos, devido ao esforço para pronunciar bem as palavras, recitava:

Prostrado nesta enxerga, sinto a vida Ir, pouco e pouco, procurando o nada: Pra mim não há mais sol de madrugada, Mas sim tremor da luz amortecida.

Prazeres onde estais? Longa avenida

De amores, que trilhei nesta jornada?

Tudo acabou. É justa esta pousada. Antes que dobre o sino da partida.

Feliz quem tem familia! Tem carinho

De mãe, de esposa, e, em derredor do leito,

Porém ao meu destino estou sujeito; 
Porím ao meu destino estou sujeito:

Devo, batendo as asas. sem ter ninho.

Buscar. quem sabe? um mundo mais perfeito?

(v. 67-8)

A fora o convencionalíssimo tema do limiar da morte, o mito do trabalho poético in extremis, que na literatura portuguesa possui uma tradição que recua, ao menos, até Bocage, os versos exaltam a idéia da constituição regular da familia, traindo um espirito fundamentalmente pequeno burguês.

Não se pode deixar de reconhecer uma considerável simpatia do narrador pela personagem. Note-se que, enquanto a modinha cantada por Cassi, bem como os versos declamados por Praxedes, são apenas parcialmente apresentados ao leitor, no caso de Marramaque se tem o texto completo do poema. No entanto, isto não significa uma adesão incondicional.

Apresentado como um caráter "azedo e oposicionista", há, de um lado, todo um esforço em afastar a hipótese de que a má-vontade de Marramaque para com o aclamado cantor de modinhas Cassi Jones seja lida como resultado de ressentimento pelo seu fracasso pessoal como artista, ou sua condição de solteirão. Sobre o talento dele como poeta, o narrador dá bom juizo na expressão "poeta ratê" ( $\mathrm{v}, 68)$; contudo, acrescenta, no mesmo parágrafo, que disso Marramaque não guardava mágoas: "A todos [seus colegas melhor sucedidos] gabava, sem que, por isso, não lhes notasse as falhas de caráter." (v. 68)

Contudo, num diálogo entre Cassi Jones e Lafões, o cantor de modinhas pergunta a este a razão da má-vontade do padrinho de Clara para com ele, obtendo a seguinte resposta:

Ele foi ou é poeta e tem em conta de cousa nenhuma os cantadores de modinhas. Lá na minha terra. os poetas dos fidalgos c das fidalgas nào tragam os fadistas do campo. aos quais chamam de rústicos e outras cousas piores. Em cada oficio. há sempre disso. O senhor não vê como os cocheiros desprèam os barbeiros? Cocheiro que nảo presta é barbeiro. Marramaque. velho. doente, não sabe disfarçar o seu mau juizo pelos que apreciam o violão e o tocam. cantando modinhas. (v. 105) 
É bem verdade que Lafões é desqualificado pelo narrador. O seu discernimento da "realidade" oculta sob as aparências é posto em dúvida e explicitamente rebaixado em comparação com o de Marramaque:

Lafōes era um homem simplório, que só tinha agudeza de sentidos para o dinheiro que vencia. Vivendo sempre em circulos limitados, habituado a ver o valor dos homens nas roupas e no parentesco, ele não podia conceber que torvo indivíduo era o tal Cassi; que alma suja e má era a dele [...]

Muito diferente do guarda [Lafoes] era Marramaque. cujo âmbito de vida sempre fora mais amplo e mais variado. Abraçava um maior horizonte de existência humana... (v, 70)

Entretanto, não se deve desconsiderar o fato de que na explicação dada por Lafões a Cassi Jones, a personagem trata a incompatibilidade entre o padrinho de Clara e o cantor de modinhas como um problema de rivalidade entre profissionais de diferentes "oficios". Se a personagem, como quer o narrador, "só tinha agudeza de sentidos para o dinheiro que vencia", tem, graças a esse pragmatismo verdadeiramente primário, condições de encarar o conflito ético $\mathrm{e}$ estético entre os dois rivais desde o ponto de vista do fenômeno da profissionalização da produção artistica.

Num certo aspecto, Marramaque pode ser lido como figuração do processo vivido pelo meio intelectual brasileiro das décadas finais do século XIX:

[...] ele foi se empregar numa papelaria-livraria, na Rua da Quitanda. Freqüentada por poetas e literatos que ensaiavam os primeiros passos, nos últimos quinze anos do Império, com eles se relacionou e sempre era escolhido para secretário. gerente. tesoureiro, de suas efêmeras publicações. Deixou o emprego da papelaria, sem zanga; $e$ atirou-se às refregas e às decepções da pequena imprensa, com ardor e entusiasmo, sangue republicano e abolicionista, sobretudo abolicionista. (v. 66)

"Os últimos quinze anos do Império" a que se refere o narrador correspondem ao momento em que uma nova geração de artistas ingressa no cenário literário. Uma geração que estava destinada a ser a primeira a enfrentar as dores e delícias da passagem à condição de profissionais das letras. Viveriam o 
momento de ápice da "boêmia dos cafés" e assistiriam a sua trasformação na "boêmia dourada dos salões", na sintese feliz de Brito Broca." Louvando os versos do obscuro colega da mocidade, a personagem revela o caráter ambíguo de suas preferências estéticas. A ambigüidade, no caso, uma vez mais pode ser

II Uma outra transformação, porém já se havia operado na paisagem da nossa vida literária. em 1910. no discurso de recepção na Academia Brasileira de letras. Joăo do Rio se referia ao "depaysement" que tornara bem tristes os derradeiros anos de vida de Guimarães Passos. apressando-lhe possivelmente a morte: ao regressar do exilio, o pocta sentira-se deslocado no ambiente carioca, os companheiros de outrora se haviam aburguesado c eram agora pais de familia. ocupando posições que thes traçavam uma linha de reserva e austeridade nas atitudes enquanto a boèmia dos cafés se transformara na boêmia dourada dos saldes. Na verdade. à medida que desapareciam os "últimos boêmios". surgia uma fauna inteiramente nova de requintados. de dândis e "raffinés". com afetaçôes de elegància. num círculo mundano, em que a literatura era cultivada com um luxo semelhante àqueles objetos complicados. aos paraventos japoneses do "art-nouveau". Em lugar dos paletós surrados, das cabeleiras casposas, os trajes pelos mais recentes figurinos de Paris e Londres. os gestos langues e displicentes dos "blasés". que constituiam a chamada "jeunesse dorée": em substituição às mesas de cafès. os clubes e saloes chiques, onde imperava o csnobismo e se aonsclhava o último livro de D'Annunzio à grande dama que não suportava Paul Bourget." A vida literária no Brasil - 1900. Rio. MEC.. 1956. p. 31. Na crônica "A Sercia". escrita em 1923. Coclho Neto dá um testemunho desse processo: "Quando estreei nas letras a Boêmia era a principal musageta. Sem ela não se subia ao Parnaso: sem cla não se conseguia uma gota d’água de Castalia. O desvario era a norma do viver. Ter casa. para que. se havia o teto do céu. constelado de estrelas? Horas de refeição. isso era para a burguesia. O poeta devia ser livre como os pássaros: e. como o sofrimento comovia as almas delicadas. $o$ ideal de todos os líricos era aparecer em público em trajos miseráveis, com a grenha derramada pelos ombros, os olhos assomnrentados. denunciando vigilias. o hálito de febre e o nidor de estômago vazio. [...] Quando Bilac e Guimaràes de Passos apareceram pela. primeira vez. na rua do Ouvidor, de polainas e flor ao peito, houve verdadeira crise no Parnaso. A principio julgaram-nos malucos. acusaram-nos. por último. de traição e se os dois se atreviam a entrar em algum café. onde se achassem reunidos literatos, era difícil conter a füria de certos intransigentes que mantinham, com orgulho, as cabeleiras leoninas. os fundilhos remendados e os cotovelos dos casacos lustrosos como a verniz". Lembre-se que na descrição que se dá de Cassi Jones, o cantor se veste "com apuro" e, antes de entoar suas modinhas, "concerta a pastinha"”. $O$ mais notável da crônica de Coelho Neto, porém, está no fato de que todo n depoimento inicial prepara a entrada no tema principal do texto, que não é outro senđ̃o o clogio do recém-falecido l.ima Barreto: "Uma das suas [da Sereia] últinas vítimas foi esse grande Lima Barreto [...] Esse escritor pujante. [...]. era um boênio de gênio. [...] Romancista dos maiores que o Brasil tem tido“. Feira Livre. Porto. Livraria Chardon. 1926. p. 35-7. Mais significativo do que o elogio ao autor que o considerara publicamente "a pessoa mais nefasta que tem aparecido cm nossas letras". é o fato de que Coello Neto identifica em Lima Barreto um exemplo da incapacidade, ou resistência. em sc adaptar ao novo lugar do artista. Ao contrário do que suas palavras, a principio, podem levar a crer. nào eran só as polainas e tlores na lapela que distinguiam a nova geração dos seus precedentes. mas um sentido profissional. A apresentação a esse mesmo volume de crônicas revela com admirável clareza essa consciència. Intitulada "Pregăo". ela explica o nome dado à coletânea. desenvolvendo a analogia entre seus textos e as mercadorias de uma feira livre. "Entra o comprador. vai ao que busca passando por tendas e balcoes a ver o neles há. Detém-no aqui. ali a curiosidade natural. Compra ou...guarda e passa. Em contraste com esse mistifório de negócio. não raro. encolhido a um canto. um poeta humilde. às vezes cego (também era Homero) canta ao som de viola fanha. É também mercador: vende cantigas tristes ou motejos que fazem rir."(p. vi) 
lida no próprio nome da personagem. Marramaque ${ }^{12}$ é termo derivado do árabe maroma, que significa, "corda grossa; cabo, calabre"; e ainda, "corda em que se equilibram funâmbulos, arlequins e certas personagens cômicas". 13 As dificuldades que a personagem semiparalitica tem para se mover se reproduzem no instável equilibrio de sua opções literárias. Balançando entre a crítica humoristica aos derramamentos emocionais do poema que recita na festa de Clara e suas simpatias pelos versos não menos sentimentais do amigo falecido, Marramaque figura as oscilação entre o espírito irreverente do arlequim e a tendência emotiva do pierrô.

Vale notar também que o legado dos versos escritos pelo infeliz Aquiles Varejão, no mal recortado estilo do "mal-do-século", é um elogio das relações familiares estáveis. À beira do seu leito de morte, o "eu-lirico" não desejaria ter sua amada, mas uma "esposa"; e aquilo do que se ressente não é dos excessos cometidos, ou da perda deles com a próxima morte, e sim a ausência de uma "familia". O modelo literário da predileção de Marramaque possui certos traços mais exagerados do espirito romântico. Porém, mais e mais se carrega da fatia mais "bem-comportada" das aspirações burguesas.

Dessa disputa da qual Cassi, Praxedes e Marramaque tomam parte, o único a sair derrotado, de acordo com o público, é o segundo. Ridicularizado, alvo de um aplauso condescendente que mal encobre o riso, sua "proposta literária" parece duplamente anacrônica: por não responder ao momento estético, e por desconsiderar o gosto de sua platéia. O sentimentalismo formalmente calculado dos versos que recita não desafiava os artistas nem empolgava o público.

Quanto aos demais participantes, a impressão inicial é de equilibrio entre os dois. Se a canção interpretada por Cassi cativa Clara e boa parcela da assistência, o recitativo de Marramaque também encontra o favor do público. Contudo, vale lembrar que, no capitulo VIII, o padrinho de Clara é assassinado, a mando de Cassi. A solução final para a disputa não recai pura e simplesmente na receptividade popular dos duelistas.

12 Para a ctimologia do nome Marramaque ver MACHADO. José Pedro. Dicionário Etimológico da Lingua Pormguesa. Lisboa: Livros Horizonte. 1977, v. IV. p. 68.

13 FERREIRA. Aurélio Buarque de Holanda Novo dicionário da lingua porfuguesa. Rio: Nova Fronteira. 1986, p. 1095. Outra variante de maroma, o vocábulo maromba, aparece logo a seguir no referido dicionário, registrando-se entre outras acepçôes: "vara com que os funâmbulos ou arlequins mantêm o equilibrio na maroma": "situaçào que se sustenta com dificuldade" c "atitude dúbia de quem não quer se definir, aguardando os acontecimentos" (p. 1095-6). 


\section{Sedutores e conquistadores}

Uma linha de leitura do sedutor nas versões finais de Clara dos Anjos merece atenção especial. Pode-se ler Cassi como encarnação de uma nova ética, uma ética dos tempos modernos. que teria uma dimensão politica de relevo, e encontra sua expressão acabada n'O Principe, de Maquiavel.

Como se viu, no pequeno romance, a cena capital do desencadear-se do processo de sedução se passa na festa de aniversário na casa de Clara.

A chegada de Cassi Jones à festa é narrada nos seguintes termos:

Entrou. Houve um estremecimento que percorreu os convivas. como um choque elétrico. Todas as moças. das mais diferentes cores, que. ali. a pobreza e a humildade de condição esbatiam e harmonizavam. logo o admiraram na suat insigniticincia geral, tão poderosa é a fascinaçăo da perversidade nas cabeças femininas. Nem César Bórgia. entrando mascarado, num baile à fantasia. dado por seu pai. Alexandre VI. no Vaticano. causaria tanta emoçào. Se não disseram: 'É César! l' Cesar!' - codiIharam: "É ele! É ele!"(v. 78)

A sensação eletrizante causada na platéia pela chegada de Cassi nada deixa a dever à entrada de um artista de sucesso em um programa de televisão. Contudo, mais que isso, a comparação com César Bórgia é significativa. Em seu O Principe ${ }^{14}$, Maquiavel apresenta a figura do duque como a forma acabada do novo político: “...eu não poderia desejar melhores normas para oferecer a um príncipe novo do que o exemplo das ações do duque [César Bórgia]."(p. 30)

Sem qualquer espécie de escrúpulos, Bórgia atropelava seus oponentes. rompendo acordos e alianças conforme os seus interesses, observando as velhas regras do jogo político apenas naquilo que the era útil ou favorável.

A associação da figura de César Bórgia aos aspectos. na opinião de Lima Barreto, mais funestos do mundo moderno. aparece com clareza em um artigo do autor publicado na Gazeta de Noticias, em 26 de outubro de 1920. Ali, comentando o livro Estudos, de Albertina Berta, ele escreveu:

[s.d].

it MACHa VEllli. Niccoló. O Principe. Trad. Torrieri Guimaràes. Sào Paulo: Ilemus. 
São eles [os burgueses] sem educação e sem gosto algum: com a crueza dos condottieri. não têm como estes o senso da beleza e da arte.

Nietzsche. devido à convivência em Bâle com Burckhardt, tinha uma grande admiração por essa espécie de gente; mas. como sempre, a sua admiração se encaminhava para o pior, para César Bórgia, o ignóbil César Bórgia, certamente fratricida c, talvez. incestuoso.

$[\ldots]$

O senhor D'Annunzio é um retrógrado. os seus ideais não são os dos nossos tempos; ele sempre sonhou com um ducadozinho italiano da Idade Média. em que pudesse dar exansão aos seus infrenes pendores para a volúpia e para a crueldade. Não há nele nenhuma simpatia pelos homens; a sua arte nào é uma interrogação diante do angustioso mistério da nossa existência. do destino e sentido da nossa vida: é uma apologia do sangue. da volúpia e da crueldade. A musicalidade da lingua italiana ilude muito...

Duque de Fiúme, ele encheu as prisões e. se não faz execuções. com um machado medieval, tirado a algum museu italiano. $\dot{e}$ porque teme o inimigo mais poderoso que o vigia.

César Bórgia, o terrivel. fez o mesmo diante de Carlos VIII. rei de França. (XIII. 120-2)

A alusão à figura de César Bórgia em conexão com o filósofo alemão e Gabriele D'Annunzio, dados como símbolos do ideário da burguesia, torna-se muito mais significativa, no trecho, uma vez que Lima Barreto explicitamente menciona o caráter enganosamente sedutor da língua da poeta (e também de César Bórgia). E tal poder de sedução emanaria justamente da "musicalidade da lingua italiana [que] ilude muito".

Pois o Cassi Jones de Lima Barreto é igualmente alguém que instrumentaliza a velha tradição romântica da modinha para seus fins de sedutor, aproveitando-se da boa-fé dos que ainda crêem no amor antigo, atropelando os que se colocam no seu caminho, como o padrinho de Clara, que é assassinado. O cantor de modinhas seria, nesta ótica, mais do que um devorador de corpos, mas o emblema dos tempos modernos, devorando aqueles que não estão aptos a viver neles, e que, apegados a valores e ética não mais vigentes, são eletrocutados pela sua energia.

Is Note-se que, do ponto de vista onomástico. o papel do sedutor no conto homônimo é desempenhado por Júlio. "sinònimo"de César, que tanto aponta para o soberano romano, quanto para o Duqque Valentino. Já na versão final, ele é Cassi Jones de Azevedo. Em nota. os cditores das Obras Completas informam que na publicação em folhetim. se grafou Cassy Jones, tendo sido feita 


\section{Mezzo bestia e mezzo uomo}

O traço sedutor do César Bórgia que Maquiavel constrói n'O Principe não escapou a Renato Janine Ribeiro. $\mathrm{Na}$ apresentação ao volume de ensaios $A$ Sedução e sutuas Máscaras, ele diz:

O demonismo é também uma categoria politica lalém de ser ética]. Gregorio Maranon escreveu. há algumas décadas. um Don. Juan e o donjuanismo em que - a despeito dos preconceitos mais tolos. de respostas muito simplistas soube formular questöes simplesmente extraordinárias. Diz: "o donjuanismo. em sintese, não passa da aplicaçào do maquiavelismo ao amor humano". Maquiavel. aos olhos de muitos. já no século XVI. encarnava de algum modo o diabo: 1/achevill é um personagem de Christopher Marlowe no Judeu de I/alta (1590?). que podemos traduzir como Mauquiavel ou Demojimior. I: Don Juan. nas versòes de Molière e Mozart. as mais conhecidas. lermina agarrado pelo demônio. Mais que essa semelhança. porém. o fundamental é que Don Juan visa ao poder em suas relaçoes (aparentemente) amorosas: sacrificar as mulheres à sua glória. pela glória dominar os homens. Os valores morais perdem-se em favor dessa meta suprema. a política ocupando o lugar dos afetos. O paralelo é claro entre essa prática e a representaçăo usual que se tem do maquiavelismo com os fins justificando os meios. ou (em termos menos preconceituosos) com a prevaléncia da política sobre a moral.(p. 15)

A comparação entre a excitação causada pela chegada de Cassi à festa suburbana com a que causaria a entrada de César Bórgia em um baile do seu tempo pode ser lida como algo além de uma metáfora. Mais do que evocar a figura do duque Valentino, o sedutor de Clara encarna uma nova estrutura de relações entre o artista e seu público, no limiar de uma nova era da comunicação no Brasil.

a opção por Cassy na primeira ediçào em volume (1948). correção que eles mantiveram. "mas com dủvida quanto à tônica. já que a mảe tinha pruridos anglicistas e aquele ' $y$ ' nă é sem razào." ( $v$. 296). $\Lambda$ artificialidade do nome, reforçada pelo descompasso entre o apelido de Azevedo e os prenomes à inglesa. faz pensar na influència dos artistas de cinema norte-americanos. por aquela época já razoavelmente populares no Rio de Janciro. 
O sedutor possui, ao mesmo tempo, marcas do favorito de Maquiavel e de Don Juan. E deste último, não lhe falta sequer o famoso catálogo em que são arroladas suas conquistas:

Quando o velho Manuel de Azevedo falou $\mathrm{cm}$ papéis escritos à máquina. trazendo indicações de datas e a narração dos fatos de suas complicações com a policia e a justiça. Cassi assustou-se. Quem estaria fazendo aquele trabalho surdo? Nào era a primeira vez que tivera notícia da existência desse caderno misterioso e misteriosamente distribuído pelo correio. Dissera-lhe um investigador de uma delegacia suburbana que, logo que havia mudança de delegado ou de comissário. numa delas. o novo delegado ou o novo comissário recebia o tal caderno. Apavoravathe essa perseguição nas trevas, talvez segura que, aos poucos. o ia minando. (v. 109)

Enquanto Don Juan "é um triunfante, alegre e divertido, sempre vibrando", nas palavras de Álvaro Valls ${ }^{16}$, circula pelo submundo dos subúrbios a espreitar suas vítimas como um animal de rapina. Nesse aspecto, ele se aproxima mais da face de César Bórgia, mezzo bestia e mezzo nomo 17 .

Assim, é uma espécie de Don Juan expulso para os infernos ${ }^{18}$ de antemão, mas que nem por isso abandona sua trajetória voraz. Até pelo contrário, por essa mesma razão, deverá seguir interminavelmente na sua carreira de seduções. Afinal de contas, o "show" não pode parar...

\section{RESUMO}

Através do exame cuidadoso de um dos episódios do romance Clara dos Anjos. de Lima Barreto. procura-se oferecer uma leitura deste trabalho do autor que destoa da fortuna crítica limabarretiana. situando a narrativa no cenário das transformações técni-

16 "Os sedutores românticos" In: RIBEIRO, Renato Janine. A sedução e suas mciscaras. São Paulo: Cia das Letras, 1988, p. 119.

17 A expressão. cunhada por Maquiavel no capitulo XVIII d'O Principe. remete ao preceptor de Aquiles. o centauro Quíron, metade animal. metade fera. utilizado como representaçào ideal das naturezas essenciais do caráter de um lider.

18 Lembre-se que depois das primeiras aventuras do fitho. seu pai o proibe de frequientar os ambientes comuns da casa, condenando-o a viver nos porões da residência. 
cas pelas quais passava o Brasil no periodo e buscando interpretá-la desde a perspectiva da emergência de um mercado de (re)produção de bens culturais em larga escala no Brasil do começo do século XX.

Palavras-chave: Lima Barreto, modernização, sedução.

\section{ABSTRACT}

By means of a careful reading of a central episode from Lima Barreto's Clara dos Anjos, this article tries to relate the writer's work to the birth of mass media (re)production processes in early 20 th century.

\section{REFERÊNCIAS BIBLIOGRÁFICAS}

ALVAREnGA. Oneyda. Misica popular hrasileira. 2.ed. São Paulo: Duas Cidades. 1982 (O Baile das Quatro Artes).

BROCA. Brito. A vida literária no Brasil - 1900). Rio de Janeiro: MEC - Serviço de Documentação. 1956. (Coleção Letras c Artes. 5)

CANTARES BRASILEIROS. Álbum discográfico duplo. com encarte. Coord. Fernando Gerardó. Companhia Internacional de Seguros. 1977.

COEL.HO Neto. H. M. Feira livre. Porto: Livraria Chardron. 1926.

COUTINHO. Afrânio (org.). Aliteratura no Brasil. 2. ed. Rio de Janeiro: Sul-Americana. 1968-70, v. 4.

CRESPO. Gonçalves. Miniaturas. 6. ed. Lisboa. Empresa Literária Fluminense. 1922. FERREIRA. Aurélio Buarque de Holanda (org.). Novo Dicionário Aurélio. Rio de Janeiro: Nova Fronteira. 1986.

LIMA BARRETO. Afonso Henriques de. Obras Completas. Org. de Francisco de Assis Barbosa et al. São Paulo: Brasiliense. 1956, v. V (Clarados Anjos). XIII (Impressões de leitura) e XIV (Diärio intimo).

LINS, Osman. Lima Barreto e o espaço romanesco. São Paulo: Ática. 1976. (Col. Ensaios. 20).

LUCAS. Fábio. Ocaráter social da fição do Brasil. Sào Paulo: Ática. 1985. (Principios. 13).

MACHADO. José Pedro. Dicionário Etimológico da Lingua portuguesa com a mais antiga documentação escrita e conhecida de muitos dos vocábulos estudados. 3 .ed. Lisboa: Livros Horizonte. 1977, v. IV.

MACHIAVELlI, Niccoló. O Príncipe. Trad. Torrieri Guimarães. Sào Paulo: Ilemus. [s.d.]. 
MATOS, Gregório de. Poemas escolhidos. Seleção, introdução e notas de José Miguel Wisnik. São Paulo: Cultrix. [s.d.].

MILLIET, Sérgio. Diärio crítico de ... . Sào Paulo: Martins, 1955. v. VIII.

RAEASSA. Gregory. O negro na fiç̧ão brasileira. Meio século de história literária. Trad. Ana Maria Martins. Rio de Janeiro: Tempo Brasileiro, 1965 (Biblioteca de Estudos Literários, 4).

RIBEIRO, Renato J. (org.). A sedução e suas máscaras. São Paulo: Cia. das Letras. 1988. RODRIGUEZ, Benito Martinez. "Catulo da Paixão Cearense: a derradeira vítima de Odete Roitman". Letras, Curitiba, n.44, p. 37-47, 1995.

Duelo ou dueto: a indecisa posição da literatura frente ao mundo moderno em Clara dos Anjos de Lima Barreto. São Paulo. Dissertação (Mestrado) FFLCH-USP.

SEVCENKO. Nicolau. Literatura como missão. Tensões sociais e criação cultural na Primeira Repuiblica. São Paulo: Brasiliense, 1983.

SILVA. Hélcio Pereira da. Lima Barreto, escritor maldito. Rio, [s.e.]. 1976.

SÜSSEKIND, Flora. Cinematógrafo de Letras. Literatura, técnica e modernização no Brasil. São Paulo: Cia. das Letras, 1987.

TEIXEIRA. Vera Regina de. "Clara dos Anjos de Lima Barreto: biópsia de uma sociedade". In: Luso-Brazilian Review. Madison:, Wisconsin, v. 17, n.1, p.41-50, 1980. 